including a member of the economic staff of the Minister, is suggested to secure the proper handling of day-to-day administration and that local authorities, private developers and landowners have ready access to informed advice and authoritative direction.

Such is the bare outline of the scheme and of the argument and principles upon which it is based. The three fundamental principles are unexceptional and are not novel. They have their roots deep in the history of British thought about the land, but for the first time they are here woven into a single pattern for the utilization of the land in the national interest. The lucid analysis with which they are supported should command widespread approval; for there is clear evidence of the forward-looking mind and of the desire to provide for change and the adaptation of system and policy to meet definitely ascertained needs.

There can be no doubt as to the opposition which is likely to be aroused to certain of the proposals : the report points unmistakably to the clash between private and national interests which must be resolved if reconstruction and planning on any adequate national scale are to be possible either now or after the War. That is a task which will require the help of all citizens of goodwill and of vision, if only in the task of education. Moreover, in regard to the central planning authority, the report gives us yet another proposal, although the resemblance to that of the Scott report is more real than might at first sight appear. Less emphatically but no less decisively than the Scott Committee, the Uthwatt Committee distinguishes between planning and development, and although the duties of the Central Planning Commission are less explicitly defined by the Uthwatt Committee, it is clear that a similar type of body is envisaged, although the Uthwatt Committee suggests a body of part-time commissioners, as against a mixed body of full-time and part-time commissioners.

The exact form of the machinery to be established, however, should present no real difficulty now that the problem has been so firmly delineated, the questions to be asked clarified and the principles upon which a solution must be based enunciated with precision and prescience. Already it is clear that the Uthwatt Committee has produced a really outstanding State paper, which will be memorable, both for its intrinsic qualities and for the test it will provide of the capacity of democratic institutions to shape themselves and society to serve the needs of a new age.

\section{A VETERINARY EDUCATIONAL TRUST}

$\mathrm{I}^{\mathrm{N}}$ $\mathrm{N}$ his speech at the Mansion House recently, at the luncheon held in the course of the congress of the National Veterinary Medical Association of Great Britain and Ireland, Dr. W. R. Wooldridge, the president, announced the formation of a National Veterinary Educational Trust. This development is one that is likely to have a profound influence upon the value of veterinary services in the future and is a result of the increased awareness, within and without the veterinary profession, of the importance of animal health and of the place it must take in the national economy.

This century has seen revolutionary changes in the approach to the maintenance of animal health. At the close of the nineteenth century the development of the Pasteurian concept paved the way for the eradication of certain of the more serious scourges, and for a time achievement in this sphere was mainly concerned with infective processes. The advances made were immense and a new type of veterinarian came into the field, armed with a microscope and trained in the methods of microbial preventive medicine. His achievements were of a high order. Animal diseases that had impeded progress in many countries were brought under control : glanders in Great Britain, rinderpest in South Africa, Texas fever and others are examples of diseases on which successful work was done.

The discovery of vitamins early in this century has led to the realization that these dietary constituents are of great importance to domesticated animals, as they are to man. Later, largely as the result of the start given by South African veterinary workers led by Theiler, certain minerals were found to be indispensable to the life of grazing animals on some types of land. Lack of phosphorus compounds in the pastures had thrown much farm land in South Africa out of production because cattlefarming could not be made profitable, and by the addition of phosphates to the food supply of the cattle the economy of these areas was revolutionized. In addition, calcium, cobalt, copper and other minerals are now known to be essential constituents of the diet of animals and, in many parts of the world, including Great Britain, pastures have been found to lack these elements. The rectification of mineral nutritional deficiency is an important and complex question.

The ravages of parasitic worms infesting livestock have been serious. The life-cycles of many helminths that have been unravelled in recent years are almost unbelievably complex, even to those who know that of the liver fluke; a large number of species of worms is involved, and an extraordinarily wide variety of changes of environment and host is resorted to by different worms in order to ensure a return to a victim of the original species, so that the continuity of the parasite may be maintained. Surely parasitic helminths are the most spendthrift gamblers in existence. Modern intensive grassland husbandry tends to favour the existence of bowel parasites of grazing animals, but fortunately advances in knowledge of the bionomics of parasitic worms, especially during the last two decades, have provided measures that can be used to circumvent the invaders.

To meet the threat of these chemical and biological hazards to the health of our economic animals, extensive knowledge of all the factors involved is required, and the veterinarian is the key link in the chain necessary for the application of the countermeasures. 
Chemotherapy for worm infestation and for diseases caused by Protozoa, and, nowadays, even for the control of certain types of bacterial infection, is used on a tremendous scale on animals. Here again the veterinarian is a key man.

The outlook has changed from consideration of the requisite bottle of medicine for treatment of the individual case after illness has become apparent, to the design of measures for application to the animals as a whole, so that disease may be prevented. The name 'veterinary surgeon' almost indicates too accurately the function of the older type of practitioner, compared with that of the modern veterinarian.

Changing agricultural practice has introduced different and new animal disease problems. Foodstuff economies, increased transportation facilities for animal produce and the increased speed of transport between countries have all been contributing factors in these dangers inherent in modern farming. Diseases occur now on farms in Great Britain that were unheard of a generation ago, and not because they were unrecognized previously. Certain metabolic diseases are examples of this trend. The food supply of modern nations demands greater use of highquality animal products than in the past, and these demands will be intensified in the future. In the absence of adequate supplies of certain of these foodstuffs, human health is menaced, and much active disease in human beings is caused if disease germs are allowed to be present in animal foodstuffs when they reach the consumer. These dangers to human health are, of course, even greater during war-time than in peace. Here again are examples of problems with which the veterinarian must be prepared to deal.

In his presidential address to the National Veterinary Medical Association, Dr. Wooldridge elaborated in some detail his ideas of the manner in which animal disease should be prevented and controlled in the future. He advocated the formation of an Animal Health Corporation, with governors appointed by the State and with powers akin to those of the British Broadcasting Corporation, policy being decided by the Government, but the Corporation having great freedom in the direction of its execution. This Corporation would be responsible for the activities of a complex staff, including specialists in the several branches of the work, practitioners to do the work on the farms, research workers, and a service to ensure that foodstuffs of animal origin are of the necessary quality and free from danger to the human consumer.

Those responsible for policy realize that the future veterinarian must have the best possible mental equipment if he is to play his part. Governments have done much to provide the necessary training, but Great Britain has lagged seriously behind others in this respect, though some improvement has been made during recent years. It is felt that something more is required for higher veterinary education than can be provided from Government sources and, indeed, that public provision additional to Government subsidy is advisable, so that instruction on the widest possible basis free from official control may be available.

The National Veterinary Educational Trust now announced is intended to provide the finances for the extension of the educational organization. An influential board of directors to manage the Trust has been appointed, and it is estimated that a minimum of $£ 1,000,000$ will be required. Government departments support the aims of the Trust, and it is anticipated that the necessary funds will be forthcoming.

The Trust would provide scholarships to enable deserving students to become veterinary surgeons, and fellowships and studentships so that those who have graduated may pursue courses of study, or undertake research at home or abroad. Equally, grants would be made to enable graduates aspiring to become veterinary teachers to undertake the necessary post-graduate research, and to assist veterinary surgeons in general practice to take refresher courses. On the other hand, every effort would be made to improve the standard of teaching at veterinary schools and increase liaison with the universities.

The formation of an Animal Health Organization, backed by an active and well-financed Veterinary Educational Trust, such as are envisaged in these proposals, would bring together veterinarians and other workers in many fields bordering on their subject and would give a much-needed stimulus to veterinary studies in Great Britain.

\section{ADMINISTRATIVE EVOLUTION : SERVICE OR TYRANNY?}

\section{The Managerial Revolution}

Or What is Happening in the World Now. By James Burnham. Pp. iv +271. (London: Putnam and Co., Ltd., 1942.) 7s. 6d. net.

7 HE increasing importance of the scientific or technical worker in industry was the theme of one of the most suggestive chapters in Prof. A. M. Carr-Saunders and Mr. P. A. Wilson's study of the professions. Despite, however, all the attention being directed to scientific management, whether through the work of the Institute of Public Administration or the Institute of Industrial Management, the social consequences and implications of the assumption by the technical and scientific staffs of an increasing degree of responsibility for the larger industrial units characteristic of to-day have attracted little attention. Prof. Carr-Saunders and Mr. Wilson's observations, like Mr. S. W. Smith's subsequent paper on the place and function of the administrative and technical worker in the new forms of economic structure, presented at the British Association meeting in 1936, have largely escaped comment. Certainly none of the professional associations of technical or scientific workers appears to have initiated any action to meet the developments and needs thus forecast.

There would be little dissent to-day from the view that organization is a technical problem and that the administration and management of any enterprise must be governed by these few fundamental principles of organization which have been laid bare by the work of Taylor, Fayol, Follett, Dennison, and 